\title{
CORRELATION BETWEEN MAXIMUM DRY DENSITY AND COHESION OF REMOULDED NSUKKA CLAYS
}

\author{
C. C. Ikeagwuani1,*, 0. P. Ogbonna ${ }^{2}$ and T. T. Ijioma ${ }^{3}$ \\ 1,2,3, DePARTMENT OF Civil ENGINEERING, UNIVERSITY OF NigERIA, NSUKKA. ENUGU STATE. NIGERIA \\ E-mail addresses:1 chijioke.ikeagwuani@unn.edu.ng, ${ }^{2}$ ogechiogbonna2008@gmail.com, \\ 3 ijiomatriumph@gmail.com
}

\begin{abstract}
Due to the ever increasing cost of laboratory equipment to determine soil parameters such as cohesion and maximum dry density and the enormous time and energy dissipated in such experiment, this research work was attempted in order to investigate the possible correlation between cohesion and maximum dry density. Thirty remoulded clay samples obtained from Nsukka were used for this investigation. The clay samples were categorized into clay of low plasticity (CL), medium plasticity (CI) and high plasticity $(C H)$ after preliminary tests have been carried out on them. To determine the correlation between cohesion and maximum dry density, unconsolidated undrained triaxial test and compaction tests were conducted on all samples and their cohesion and maximum dry density values determined appropriately. Using regression analysis, correlations were developed for the various categories of clay soils. The correlation coefficient, $R$, obtained for the $C L, C I$ and $C H$ soils were $57.8 \%, 67.9 \%$ and $93 \%$ respectively. Based on this correlation coefficient, it is safe to suggest that for preliminary estimates of soils, the correlations obtained for these soils will suffice.
\end{abstract}

Keywords: Cohesion, Compaction, Correlation, Maximum dry density, Nsukka Clays, Triaxial compression test

\section{INTRODUCTION}

Some empirical relationships exist in geotechnical engineering between one soil property and another [1]. This is because some soil properties such as coefficient of consolidation, drained shear strength parameters are time consuming and could also be pretty expensive to conduct in the laboratory. Its negative effect will be highly felt when large amount of samples are required to be tested so as to determine the geotechnical properties of either the preliminary or engineering properties of the soil. To this end, it is pertinent to develop empirical models that will factor in two key aspects of construction which are saving cost and time. Any correlation between one physical parameter and other that does not consider these key areas may not be of any advantage. According to [2], the correlation between unconfined compressive strength of clays and their standard penetration resistances given by [3] is of no advantage as the very expensive nature of standard penetration test renders it practically unusable. It is noteworthy that while it may save considerable time, energy and cost using empirical relationship developed for soil, it should be noted that soils by their very nature are highly heterogeneous and so application of some of the empirical relationships should be done with utmost caution. Interpretation of the results arising from it should be done by highly competent geotechnical engineer. Despite the shortcomings of these correlations between one physical property and another, they are still used occasionally especially when time for the construction of a project is of great importance. Soil properties such as the maximum dry density and cohesion of soil are highly necessary especially when estimating the bearing capacity of footings using the conventional bearing capacity equations like the Terzaghi's bearing capacity equation. As earlier pointed out, cost and time are of paramount importance during construction activities so carrying out the test separately will definitely increase the cost of the construction. Therefore a correlation between these soil parameters will be highly welcome.

At this juncture it is pertinent to look at other existing empirical correlation available and how they tend to solve some peculiar problem(s) in geotechnical 
engineering. Youssef and Gihan [4] attempted an investigation on sandy soils to determine the correlation between relative density and compaction test parameter. Using twenty soil samples, they were able to develop correlations between relative density, coefficient of uniformity and maximum dry density.

Khafaji [5] using standard proctor compaction method carried out an investigation into the relationship between Atterberg's limits and soil compaction. The soils used were obtained from Iraq and USA and a comparison was made between the results obtained from both countries. The results were given separately as:

$$
\begin{aligned}
& \rho d \max =2.44-0.02 w_{p}-0.008 w_{l} \\
& \rho d \max =2.27-0.019 w_{p}-0.003 w_{l}
\end{aligned}
$$

Equations 1 and 2 are for soils in Iraq and USA respectively. Where $\rho d \max$ represents maximum dry density, $w_{p}$ signifies plastic limit and $w_{l}$ is liquid limit.

Researchers [6, 7] estimate compaction parameters. Aside from the correlation existing between compaction parameters and other physical quantities there are some other correlations that have been investigated by other researchers. The well-known correlation postulated by [3] on the relationship between compression index and liquid limit for both disturbed and undisturbed soils are widely used because it assists in saving cost that would have otherwise been expended on carrying out consolidation test. The equations for both the disturbed and undisturbed soils are given by:

$$
\begin{gathered}
\mathrm{C}_{\mathrm{c}}=0.007(\mathrm{LL}-10) \\
\mathrm{C}_{\mathrm{c}}=0.009(\mathrm{LL}-10)
\end{gathered}
$$

However, most of the correlation existing in literatures mainly involves the relationship between the Atterberg's limits parameters and engineering properties. Laskar \& $\mathrm{Pal}[8]$ in their study developed an empirical relationship between plasticity index and liquid limit of soil. Three different types of soils were used during the investigation. One of the soils was a mixture of the two types of soils. The soils were collected from different locations. Two of the soils had inorganic clay of low to medium plasticity index while the last one had inorganic clay of high plasticity index. A linear curve was assumed while obtaining the relationship they gave as:

$$
\mathrm{PI}=0.7785(\mathrm{LL}-18.623)
$$

Using same set of samples, they also developed empirical relationships between plasticity index and optimum moisture on the one hand and also optimum moisture content and compression index on the other hand and the following results were obtained by them:

$$
\mathrm{OMC}=0.43(\mathrm{PI}+30)
$$

$$
\mathrm{C}_{\mathrm{c}}=0.0134(\mathrm{OMC}-7.034)
$$

Equations (5, 6 and 7) developed by [8] are good as preliminary estimates of engineering properties of soils. However, with the maximum plasticity index from the three types of soils gotten as 16.31 , using the equations for soils with higher plasticity index than 16.3, the question of acceptability from any results obtained from it will surely arise.

In another research, the pair of [2] working on tropical clays whose natural moisture content was not more than $8 \%$ below the plastic limit attempted the correlation between undrained shear strength and plasticity index and obtained the following results for the three groups of clay soils with different degree of plasticity:

$$
\begin{aligned}
\log q_{u}=1.725+ & 0.315 \frac{\sigma_{3}}{100} \\
& +\frac{\text { PI }}{100}\left(0.834-0.906 \frac{\sigma_{3}}{100}\right) \\
\log q_{u}=2.334+ & 0.0094 \frac{\sigma_{3}}{100} \\
& +\frac{\text { PI }}{100}\left(2.508-0.504 \frac{\sigma_{3}}{100}\right) \\
\log q_{u}=1.821+ & 0.131 \frac{\sigma_{3}}{100} \\
& +\frac{\text { PI }}{100}\left(1.054-0.0457 \frac{\sigma_{3}}{100}\right)
\end{aligned}
$$

Using the unified soil classification system, equations 8, 9 and 10 are for $\mathrm{CL}, \mathrm{CI}$ and $\mathrm{CH}$ groups respectively. In the development of the empirical formulars above, they also assumed a linear curve for the relationship. However, from the graphs used in obtaining the results, a polynomial of degree two would have produced a better correlation. Also, most soils found in tropical and temperate region normally have their natural moisture content above $8 \%$ of the plastic limit as they are mostly saturated.

Agarwal \& Ghanaker[9] in their research between the physical properties of soils gave the correlation:

$$
\mathrm{CBR}=2-16 \log (\mathrm{OMC})+0.07 \mathrm{LL}
$$

Equation 11 was obtained with 48 samples, however, the CBR values they obtained from the tests conducted were all less than $9 \%$ with a standard deviation of 1.8 prompting them to suggest that the correlation could only be sufficient for preliminary identification of soils. From the few available literatures on the correlations of two or more physical parameters, it is obvious that most researches are geared towards solving the twin problem of saving time and cost. This research that was undertaken to investigate the correlation between maximum dry density and cohesion of remoulded Nsukka clays consider primarily the cost due to the high cost of carrying out undrained triaxial test. The cost for the procurement of the equipment when 
compared with compaction equipment is exorbitant and this may ultimately help to drive down the cost of construction.

\section{METHODOLOGY}

\subsection{Description of Study Area}

The study area of this research is Nsukka in Nsukka local government area (LGA) of Enugu state, Nigeria. The various samples used for this research were all collected within Nsukka. Nsukka is located within the geographical coordinates of latitude: $6^{\circ} 84^{\prime} 29^{\prime \prime} \mathrm{N}$ and Longitude: $7^{\circ} 37^{\prime} 33^{\prime \prime} \mathrm{E}$ and it has a land area of $1,810 \mathrm{~km}^{2}$. Its population was put at 309,633 according to the census conducted by the National population commission in 2006 [10].

\subsection{Geology of Study Area}

Nsukka LGA is bordered by Igbo-Etiti LGA to the south, Igbo-Eze south LGA to the north, Udenu to the northeast, Isi-Uzo to the east and Uzo-uwani LGA to the west. Most of the terrains are hilly with undulating slopes. The predominant soil found within the area is lateritic soil which could extend to a depth of four meters measuring from the ground surface. However, some consolidated clay deposits are also found at different locations within Nsukka.

\subsection{Sample Collection and Identification}

All the clay samples used for this research were collected from five different locations scattered within Nsukka area where clays of sizeable quantities could be found. To obtain the remoulded clay samples required for this research, pits were excavated at the collection points to the depth of the clay stratum. The clay deposits were overlain by a thick layer of lateritic soil and gravel found from the top surface and also with some vegetative matter. Samples were collected with a trowel and then placed in an air-tight container to prevent the ingress of moisture and also to avoid jeopardizing the result of the test that would be carried out for the determination of the available natural moisture content of the clay sample the laboratory.

At each of the five different locations, six different sets of remoulded clay samples points were obtained for this research. And of the six sets of samples collected from each of the locations within Nsukka, the first set of samples designated as HP-1, HP-2, HP-3, HP-4, HP-5 and HP-6, and the second set of samples designated as ARCH-1, ARCH-2, ARCH-3, ARCH-4, ARCH-5 and ARCH6 were all collected at a depth of 0.5 metres below the ground surface. The first sets of samples were obtained at the shore of a naturally occurring pond situated at
Hilltop district in Nsukka town while the second set of samples were obtained from a construction site situated at Ashore spring in Onuiyi. The third location was at Ashore spring in Onuiyi but samples were collected at an offset of 3 metres from the spring. The five samples collected were designated as ASH-1, ASH2, ASH-3, ASH-4, ASH-5 and ASH-6. The clays were all obtained at a depth of 1.5 metres below the ground surface.

Other locations include the Ndiagu and Government residential area (G.R.A). The clay deposits from Ndiagu was found at a depth of $2 \mathrm{~m}$ below the ground surface and the samples were labelled ND-1,ND-2, ND-3, ND-4, ND-5 and ND-6. The samples collected at G.R.A were labelled GRA-1, GRA-2, GRA-3, GRA-4, GRA-5 and GRA6 and they were collected at a depth of 0.8 metres below the ground surface. Table 1 shows the depth and description of samples collected at the five different locations

Table 1: Depth and description of samples

\begin{tabular}{|c|c|c|c|}
\hline $\begin{array}{l}\text { Sample } \\
\text { label }\end{array}$ & $\begin{array}{l}\text { Depth } \\
\text { (m) }\end{array}$ & Description & Location \\
\hline HP & 0.5 & \multirow{2}{*}{$\begin{array}{l}\text { Whitish-Brown } \\
\text { Brownwish- } \\
\text { White }\end{array}$} & Hilltop \\
\hline ARCH & 0.5 & & Onuiyi \\
\hline PO & 0.8 & Light Brown & $\begin{array}{l}\text { G.R.A } \\
\text { Nsukka }\end{array}$ \\
\hline ND & 2.0 & \multirow{2}{*}{$\begin{array}{l}\text { Dark Brown } \\
\text { Yellowish - } \\
\text { brown }\end{array}$} & Ndiagu \\
\hline ASH & 1.5 & & Onuiyi \\
\hline
\end{tabular}

\subsection{Experimental Procedure}

The different tests were all performed using the British Standard, BS 1377. Tests carried out include: particle size distribution, Atterberg's limits, hydrometer test, specific gravity, compaction and unconsolidated undrained triaxial tests. The results obtained from the particle size distribution and Atterberg's limits and the hydrometer test were used to classify the soil samples and also to determine the level of plasticity of the clay.

\subsubsection{Compaction Test}

Compaction of soil was done primarily to increase the density of the soil through mechanical methods. The density of the soil is achieved by expelling air from the air voids of the soil thereby increasing the shear strength of the soil which ultimately increases the bearing capacity of the soil [11]. In this study the Bristish Standard Institute, Part 4 (1990) was employed in the compaction test and this was achieved by using the standard proctor mould with a $2.5 \mathrm{~kg}$ rammer falling freely from a height of $310 \mathrm{~mm}$. The soil was compacted in three layers with each of the layer 
receiving 25 blows. After the experiment, a relationship between the moisture content and the dry density was plotted on graph to obtain the maximum dry density and the optimum moisture content of the soil from the peak value of the compaction curve. The dry density of the soil was calculated from this equation:

Dry density:

$$
\rho_{d}=\frac{\rho}{1+w} \mathrm{~g} / \mathrm{cm}^{3}
$$

Bulk density:

$$
\rho=\frac{M}{V} \frac{g m}{c m^{3}}
$$

Where $w$ is the moisture content of the soil, $\mathrm{M}$ is the mass of the compacted soil and $\mathrm{V}$ is the volume of the mould

\subsubsection{Unconsolidated Undrained Triaxial Compression test}

Based on the drainage condition of the soil sample, unconsolidated undrained triaxial compression test which is one of the three types of triaxial compression test that can be conducted on soil samples to determine its shear strength parameters such as the cohesion and frictional angle of the soil, was conducted in accordance with the specification of BS 1377 Part 7(1990). In this type of test, drainage of water and consolidation of the soil is not allowed throughout the duration of the test. The test is sometimes referred to as undrained test. To carry out the test in the laboratory, triaxial equipment was used to determine the cohesion and frictional angle of the soil. British Standard Institue, Part 7 (1990) was employed in this research.

\subsection{Correlation and Regression Analysis}

Results of compaction and unconsolidated undrained triaxial tests were used in model development by plotting a graph of cohesion against maximum dry densities for the three groups of soils (CL, CI and $\mathrm{CH}$ ) in this study. Regression analysis, which is a statistical tool used largely in the field of engineering for investigating relationship between two or more variables, was used to analyse the result. Furthermore, Karl Pearson's correlation coefficient, R was used to determine the correlation between the soils' physical properties.

\section{RESULTS AND ANALYSIS}

The properties of the clay samples used in this study are presented in Table 2 . The maximum dry density of the various soil samples ranges from 13.73 to 19.3 . Out of the thirty samples used for this research, six samples fall under clay of high plasticity, 17 samples were of clay of intermediate plasticity while the remaining seven samples were categorized under clay of low plasticity.

\begin{tabular}{|c|c|c|c|c|c|c|c|}
\hline S/NO & $\begin{array}{l}\text { Sample } \\
\text { Description }\end{array}$ & $\begin{array}{l}\text { PI } \\
(\%)\end{array}$ & $\begin{array}{l}\text { Specific } \\
\text { gravity }\end{array}$ & $\begin{array}{l}\text { Maximum dry density } \\
\left(\mathrm{Kg} / \mathrm{m}^{3}\right)\end{array}$ & $\begin{array}{l}\text { Optimum Moisture } \\
\text { Content (\%) }\end{array}$ & Cohesion & USCS \\
\hline 1 & HP-1 & 27.00 & 2.365 & 18.5 & 37.25 & 77.5 & $\mathrm{CH}$ \\
\hline 2 & HP-2 & 34.20 & 2.30 & 17.2 & 27.2 & 79.2 & $\mathrm{CH}$ \\
\hline 3 & HP-5 & 20.40 & 2.19 & 19.3 & 12 & 83.5 & $\mathrm{CH}$ \\
\hline 4 & ASH-2 & 22.50 & 2.45 & 16.6 & 21.0 & 80.2 & $\mathrm{CH}$ \\
\hline 5 & ASH-4 & 20.60 & 2.44 & 17.4 & 22.5 & 78.3 & $\mathrm{CH}$ \\
\hline 6 & ASH-5 & 25.34 & 2.51 & 18.1 & 21.5 & 76.5 & $\mathrm{CH}$ \\
\hline 7 & HP-3 & 27.20 & 2.45 & 17.35 & 25 & 77.5 & $\mathrm{CI}$ \\
\hline 8 & HР-4 & 23.50 & 2.28 & 16.4 & 27.5 & 75.5 & CI \\
\hline 9 & HP-6 & 22.10 & 2.29 & 17.8 & 30 & 82.1 & $\mathrm{CI}$ \\
\hline 10 & ARCH-2 & 13.70 & 2.61 & 13.73 & 24.4 & 101.2 & $\mathrm{CI}$ \\
\hline 11 & ARCH-3 & 17.60 & 2.34 & 15.3 & 27 & 84.5 & $\mathrm{CI}$ \\
\hline 12 & ARCH-5 & 23.60 & 2.65 & 16.2 & 29 & 86.5 & CI \\
\hline 13 & ARCH-6 & 24.85 & 2.41 & 16.4 & 26.4 & 80.2 & $\mathrm{CI}$ \\
\hline 14 & PO-2 & 17.55 & 2.58 & 17.8 & 26.5 & 82.1 & CI \\
\hline 15 & PO-4 & 25.94 & 2.37 & 18.7 & 27.5 & 79.5 & CI \\
\hline 16 & PO-5 & 21.80 & 1.98 & 18.1 & 27 & 88.4 & $\mathrm{CI}$ \\
\hline 17 & ND-1 & 23.77 & 2.35 & 15.58 & 29.8 & 69.2 & $\mathrm{CI}$ \\
\hline 18 & ND-2 & 33.10 & 2.51 & 15.64 & 26.8 & 71.5 & CI \\
\hline 19 & ND-3 & 22.50 & 2.36 & 15.1 & 27.3 & 74.2 & $\mathrm{CI}$ \\
\hline 20 & ND-6 & 21.95 & 2.29 & 16.2 & 28 & 75.1 & $\mathrm{CI}$ \\
\hline 21 & ASH-1 & 14.45 & 2.55 & 18.36 & 17.2 & 82.1 & CI \\
\hline 22 & ASH-3 & 15.60 & 2.41 & 17.0 & 23.0 & 78.6 & $\mathrm{CI}$ \\
\hline
\end{tabular}

Table 2: Properties of the samples 


\begin{tabular}{llllllll}
\hline S/NO & $\begin{array}{l}\text { Sample } \\
\text { Description }\end{array}$ & $\begin{array}{l}\text { PI } \\
(\%)\end{array}$ & $\begin{array}{l}\text { Specific } \\
\text { gravity }\end{array}$ & $\begin{array}{l}\text { Maximum dry density } \\
\left(\mathrm{Kg} / \mathrm{m}^{3}\right)\end{array}$ & $\begin{array}{l}\text { Optimum Moisture } \\
\text { Content }(\%)\end{array}$ & Cohesion & USCS \\
\hline 23 & ASH-6 & 13.60 & 2.47 & 17.3 & 22.4 & 77.4 & $\mathrm{CI}$ \\
24 & ARCH-1 & 11.10 & 2.03 & 17.1 & 28 & 77.2 & $\mathrm{CL}$ \\
25 & ARCH-4 & 15.60 & 1.98 & 16.7 & 28.4 & 79.2 & $\mathrm{CL}$ \\
26 & PO-1 & 11.12 & 2.46 & 17.3 & 20.7 & 115.8 & $\mathrm{CL}$ \\
27 & PO-3 & 14.28 & 2.45 & 18.2 & 28.2 & 79.5 & $\mathrm{CL}$ \\
28 & PO-6 & 12.40 & 1.90 & 16.5 & 27.8 & 80.2 & $\mathrm{CL}$ \\
29 & ND-4 & 17.80 & 2.40 & 17.3 & 36.2 & 714 & $\mathrm{CL}$ \\
30 & ND-5 & 11.30 & 2.32 & 15.6 & 32.6 & 70.5 & $\mathrm{CL}$ \\
\hline
\end{tabular}

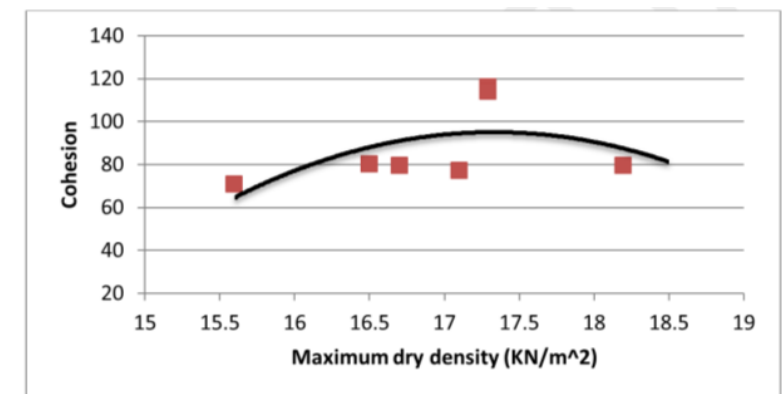

Figure 1: Correlation between maximum dry density and cohesion for CL-soils

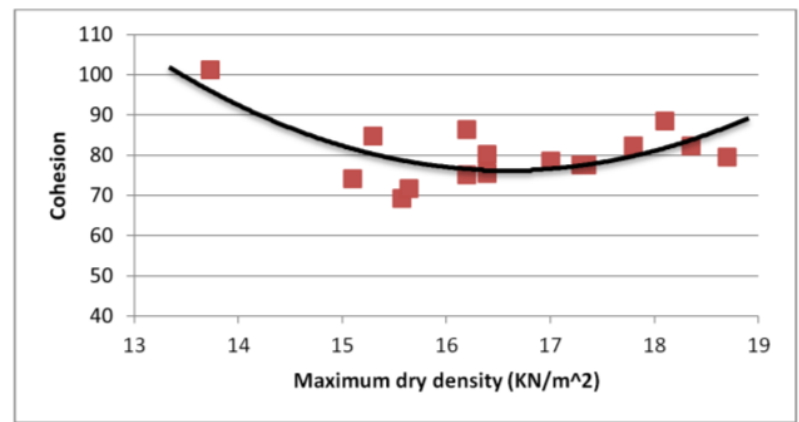

Figure 2: Correlation between maximum dry density and cohesion for CI-soils

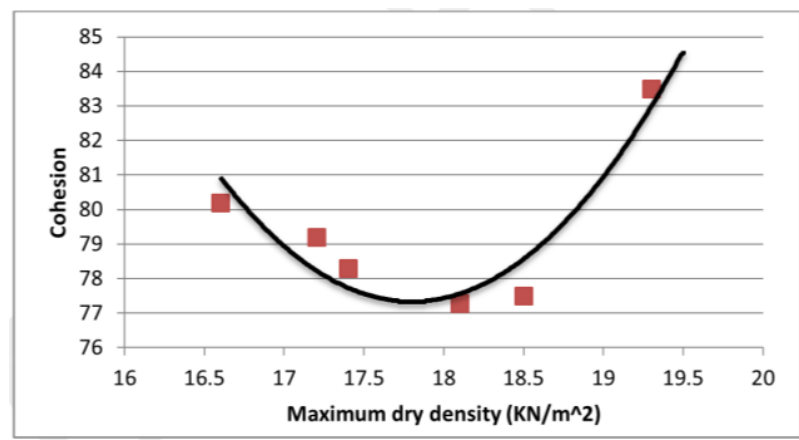

Figure 3: Correlation between maximum dry density and cohesion for $\mathrm{CH}$-soils

\subsection{Correlation for Cl-Soils}

The correlation between cohesion and maximum dry density for CL-soils is shown in Figure 1. As can be seen from the graph, a polynomial of degree two was used to fit the points. The equation obtained is

$$
C=-10.121 \gamma d^{2}+350.85 \gamma d-2945.4
$$

and it has a correlation coefficient of $\mathrm{R}=0.578$
Where $\mathrm{C}$ is the Cohesion and $\gamma d$ is the maximum dry density.

The correlation coefficient gave a conservative value. Additional data points could have helped with a better correlation coefficient. It has to be mentioned that for maximum density of CL-soils with value of less than 15 , equation 14 is not recommended for obtaining the cohesion of the soils because the values obtained from it will not give a reliable result for any constructional work. Below this point a negative cohesion result may be obtained which certainly does not give accurate results.

\subsection{Correlation for CI-Soils}

Figure 2 shows the correlation between cohesion and maximum dry density for CI-soil. Again a polynomial of degree 2 was used to fit the points in the graph. The relationship between cohesion and maximum dry density for the remoulded clays in Nsukka used for this research is:

$$
C=2.4267 \gamma d^{2}+80.5 \gamma d-743.86
$$

with a correlation coefficient of $R=0.679$. The correlation coefficient obtained for the CI-soils is relatively high when compared with that of the CLsoils. The scattered points are more and the outliers are very few suggesting that equation 15 can be confidently used for the determination of cohesion for CI-soils when the values of the maximum density for the soils are known.

\subsection{Correlation for CH-Soils}

The relationship between cohesion and maximum dry density for CH-soils is shown in Figure 3. The correlation equation and the coefficient of regression obtained are:

$$
C=2.5058 \gamma d^{2}+89.195 \gamma d-871.06
$$

And $\mathrm{R}=0.93$.

The correlation obtained for the $\mathrm{CH}$-soil is very high indicating that there exist a strong correlation between maximum dry density and cohesion for such type of soils. Equation 17 can be used with a high degree of certainty to obtain an approximate result for the value 
of the cohesion with known value of the maximum dry density of the soil.

\section{CONCLUSION}

This research work investigated the correlations between cohesion and maximum dry density for three categories of clay soils ( $\mathrm{CL}, \mathrm{CI}$ and $\mathrm{CH}$ ). Of the three types of clay soils identified in this study, the $\mathrm{CH}$-soil gave the highest correlation coefficient indicating that there exist a very strong correlation between cohesion and maximum dry density for the $\mathrm{CH}$-soil. Other types of soils gave a relatively high but conservative value. The authors believe that for preliminary estimates of cohesion and maximum dry density of soils that correlation obtained for the various types of soils could be highly helpful.

\section{REFERENCES}

[1] Sorensen, K. K. and Okkels, N. "Correlation between drained shear strength and plasticity index of undisturbed over consolidated clays," in Proceedings of the 18th International Conference on Soil Mechanics and Geotechnical Engineering, Paris, 2013.

[2] Obasi, N. L. and Anyaegbunam, A. J. "Correlation of the undrained shear strength and plasticity index of tropical clays," Nigeria Journal of Technology, vol. 24, no. 2, pp. 1-11, 2005.

[3] Terzaghi and Peck, R. R. Soil Mechanics in Engineering practice, Ist ed., New york: John Wiley and Sons, 1948.

[4] Youssef, G. and Gihan, A. "Correlation between relative density and compaction test parameters," in Twelfth International Colloquium on Structural analysis and Geotechnical Engineering, Egypt, 2007.
[5] Khafaji, A. "Estimation of soil compaction parameters by means of Atterberg's limits," Quarterly journal of engineering geology and hydrogeology, vol. 26, no. 4, pp. 359-368, 1993.

[6] Blotz, L. R. ,Benson C. H. and Boutwell, G. P. "Estimating optimum water content and maximum dry unit weight for compacted clays," Journal of geotechnical and geo-environmental engineering, vol. 124, no. 9, pp. 907-912, 1998.

[7] Jumikis, A. R. "Geology and soils of the Newark (NJ) metropolitan area," J. Soil Mech. Found. Div, vol. 94, no. 2, 1958.

[8] Laskar, A. and Pal, S. K. "Geotechnical characteristics of two different soils and their mixture and relationships between parameters, " EGJE, vol. 17, no. Bund U, pp. 2821-2832, 2012.

[9] Agarwal, K. B. and Ghanaker, K. D. "Correlation between CBR values with liquid limit and Optimum moisture content on Indian Soils," in National Institute of Technology, Rourkela Odisha, India, 1970.

[10] National Population Commission, Nigeria, "Census," Population distribution by age and sex, 2006. [Online]. Available: http://www.population.gov.ng/index.php/census es. [Accessed 10 March], 2016.

[11] Arora, K. R. Soil Mechanics and Foundation Engineering, 6th ed., Nai Sarak, Delhi: Standard Publishers Distributors, 2003.

[12] British Standard Institute, Methods of testing soils for civil engineering purposes, London: BS 1377, Part 41990.

[13] British Standard Institute, Method of testing soils in civil engineering purposes, London: BS 1377, Part 71990. 